\title{
Hjälp att bevara eller förändra? Åldersrelaterade diskurser om omsorg, stöd och service
}

Sara Erlandsson, Akademisk avhandling, Rapport $i$ socialt arbete 145. Institutionen för socialt arbete, Stockholms universitet, 2014.

Den som har kommit i kontakt med både äldreomsorgen och de insatser som ger stöd till yngre personer med funktionsnedsättningar har slagits av hur olika de två verksamhetsfälten ser ut. Syftet med Sara Erlandssons avhandling är att undersöka och problematisera dessa skillnader genom frågor om vilka mål som ställs upp för de olika verksamhetsfälten, vilka behov som tillskrivs olika grupper och hur dessa ska mötas genom olika typer av hjälp (omsorg, service, stöd). Avhandlingens teoretiska ansats är diskursanalytisk - det som studeras är presentationen av kategorier som tillskrivs olika problem, behov och rättigheter, vilka dels kan utlä- sas direkt och dels i beskrivningarna av hjälpinsatserna.

Att det finns skillnader konstateras i Erlandssons genomgång av de två verksamhetsfälten. Äldreomsorgen regleras av socialtjänstlagen där individen ska tillförsäkras en skälig levnadsnivå, medan yngre personer med funktionedsättningar kan få hjälp enligt LSS, där målet anges som att tillhandahålla goda levnadsvillkor. Hjälpformerna framstår som mer kostsamma och individanpassade inom LSS-verksamheter, där det heller inte tas ut avgifter från den som använder servicen. Ambitionsnivån för LSS-verksamheterna är högre och det är enligt Erlands- 
son möjligt att se en relation mellan senare års minskning av resurserna inom äldreomsorgen och de kostnadsökningar som följt med rättighetslagen LSS. Skillnaderna mellan de två verksamhetsfälten påverkar till och med valet av begrepp och Erlandsson väljer att undvika de etablerade begreppen omsorg och service och istället tala om hjälp.

Analyserna i Erlandssons avhandling baseras på två typer av material. Det första består av regeringens nationella handlingsplaner för äldre- respektive handikappolitiken. Det andra av hemsidor från kommunala och privata utförare av äldreomsorg respektive personlig assistans och daglig verksamhet. Här kan man anmärka lite på avhandlingens självpresentation, för det visar sig att det kapitel som handlar om forskning om hjälpinsatser för äldre och yngre också har karaktären av empirisk studie. En intressant och gedigen delstudie dessutom, som kompletterar de två övriga i en slags triangulering av de två fältens karaktäristika.

Erlandssons genomgång av forskning om hjälpinsatser för äldre respektive yngre bygger på i stort sett samtliga svenska avhandlingar inom området - 25 om äldreomsorg och 26 om verksamheter för de yngre (personlig assistans, boende med särskild service och dagliga verksamheter för personer med utvecklingsstörning, samt hjälpinsatser för personer med psykiska funktionsnedsättningar). Erlandssons undersökning visar att de avhandlingar som studerar hjälp till äldre betonat omsorgsarbetets inkännande kompetens och ofta tagit omsorgspersonalens perspektiv, medan funktionshinderforskningen värjt sig mot omsorgsbegreppets emotionella komponent och i högre grad tagit sin utgångspunkt i hjälpmottagarens situation. För de yngre finns det exempelvis 11 avhandlingar som enbart fokuserar hjälpmottagarens situation medan inga avhandlingar om äldre gör detta. $\AA$ andra sidan har hela 12 av avhandlingarna om äldre enbart fokus på hjälpgivaren, medan endast två avhandlingar om yngre har detta fokus.

I den delstudie som handlar om politik undersöker Erlandsson hur "äldre" respektive "personer med funktionsnedsättning" konstrueras som särskilda kategorier inom den Nationella handlingsplanen för äldrepolitiken (Prop. 1997/98:113) respektive den Nationella handlingsplanen för handikappolitiken (Prop. 1999/2000:79). Resultatet av studien kan sammanfattas som att funktionshinderpolitik gör samhället till ett problem för personer med funktionsnedsättning, medan äldrepolitiken gör äldre till ett problem för samhället. I det handikappolitiska dokumentet står kostnaderna inte i fokus, utan här presenteras ovillkorliga rättigheter. I det äldrepolitiska dokumentet är äldreomsorg något som produceras, förbrukas och diskuteras i termer av hjälpvolym. Där den handikappolitiska blicken riktas bakåt mot den historiska kampen för rättigheter, riktas den äldrepolitiska blicken framåt mot de ökande kostnaderna och svårigheten att rekrytera personal. Erlandssons analyser möjliggör ifrågasättanden av äldrepolitiken, som knappast vore möjliga utan kontrasteringen till det handikappolitiska dokumentet. Inom handikappolitiken lieras läsaren i den 
gemensamma kampen för lika rättigheter. Varför ser beskrivningarna inte ut så inom äldrepolitiken? Varför ser den inte ut så inom äldreforskningen?

I den delstudie som bygger på hemsidor från kommunala och privata utförare av äldreomsorg respektive personlig assistans och daglig verksamhet undersöker Erlandsson hur hjälpen presenteras och därmed, hur hjälpmottagaren konstrueras. Vem tilltalas? Vilka hjälpbehov antas den som verksamheterna riktar sig till ha, direkt eller utifrån de insatser och problem som beskrivs? Analysen bygger på hemsidor från 38 utförare av hjälptjänster. I dessa kapitel analyserar Erlandsson också bilder från de olika verksamheterna och här finns det återigen anslående skillnader. När personlig assistans avbildas placeras brukaren i förgrunden. Inom daglig verksamhet fokuseras produkterna av det arbete som utförs. Inom äldreomsorgen avbildas omsorgstagaren, men ofta omfamnad av eller vid sidan av den personal som blir bildernas förgrundsgestalter. Den som forskar om äldreomsorg vet att verksamheterna ofta avbildar händer. Så också i de material Erlandsson studerar. Men medan äldreomsorgens avbildas som uttryck för just omsorg ett par unga händer håller om en gammal hand - illustrerar den personliga assistansens händer ett kontrakt - ett handslag. Här befinner sig händerna i samma serie som domarklubban, som också används för att illustrera assistanshjälpens karaktär av rättighet. Också verksamheternas mål ser mycket annorlunda ut. Den ena verksamheten har ambitionen att förbereda och göra samhället tillgängligt medan den andra syftar till att trösta, stödja och bevara - ofta uttryckt i mål om att äldre omsorgstagare ska kunna leva som tidigare. Inflytande och delaktighet för yngre beskrivs som en fråga om att vara delaktig i samhället och äger rum på flera arenor. De äldre har inflytande och är delaktiga i den egna omsorgen, i hemmet eller på äldreboendet.

I de sammanfattande analyserna diskuterar Erlandsson de olika problempresentationer hon identifierat som två diskurser - en framtidsinriktad där syftet är att förändra och en bakåtriktad där syftet är att bevara.

Jag tycker att Erlandsson har lyckats väl med ambitionen att undersöka och problematisera de skillnader som föreligger mellan hjälp till yngre respektive äldre personer med funktionsnedsättningar. Analyserna genomförts skickligt och de skillnader som friläggs blir i vissa fall nästan smärtsamt tydliga. Det är också lovvärt att analysen inkluderar bilder, utifrån en ganska enkel analysram som fungerar fint i helheten. Den som menar att kvalitativt och diskursanalytiskt orienterade forskare inte ska inkludera enkla beräkningar kan lära en del av den tabell som Erlandsson infogat för att illustrera användningen av olika begrepp inom de två utredningar hon studerat. För det blir anslående när begrepp som diskriminering och demokrati förekommer hela 84 respektive 34 gånger inom den utredning som behandlar funktionshinderpolitik men bara fyra respektive fem gånger i den äldrepolitska utredningen. Eller när begrepp som personal och anhörig/närstående förekommer 
156 respektive 138 gånger $\mathrm{i}$ utredningen om äldrepolitiken, men bara 29 respektive åtta gånger i utredningen om funktionshinderpolitiken. Det här är enkla beräkningar men de styrker trovärdigheten i den kvalitativa analysen.

Den tydlighet som jag lovordat kan också ses som en möjlig brist. Linjerna blir väldigt rena, men blir de kanske för rena ibland? Jag håller själv på med en studie av hemsidespresentationer av äldreomsorg och i mina genomgångar är materialet mycket smutsigare och oklarare än det som presenteras i Erlandssons genomgångar, men då har ju hon å andra sidan arbetat flera vändor med sina analyser. Det här är en fråga som kvalitativa studier av policy och praktik ständigt brottas med. Hur tydliga och idealtypiska bör och får teman bli? En fråga som också väcks $i$ anslutning till detta är vad en analys av funktionshinderpolitiken och dess praktik som inte komparerades mot äldrepolitik och äldreomsorg skulle visa. Erlandsson konstaterar att det finns en tendens att idealtypiskt beskriva yngre personer med funktionsnedsättningar som aktiva och självmedvetna medborgare - som mottagare av personlig assistans. Detta innebär att personer med intellektuella funktionsnedsättningar hamnar lite i skymundan, eftersom det är svårare att presentera dem som idealtypiska. Lite av samma renodling och nedtoning tycker jag mig se i Erlandssons beskrivning av verksamheterna för yngre personer, som ju i huvudsak står som kontrast till äldreomsorgen.
Erlandssons avhandling visar att äldreforskning, äldrepolitik och äldreomsorg har mycket att lära av sina motsvarigheter inom funktionshinderområdet. Erlandsson presenterar dock inte sina resultat på det sättet och en fråga är naturligtvis om hon i högre grad borde ha tagit ställning och pekat på behov av förändring, att LSS-lagstiftningen exempelvis skulle omfatta personer som åldras till funktionsnedsättningar och som idag hänvisas till socialtjänstlagen. Jag tror att hon gör rätt $i$ att som nu lägga korten på bordet och överlåta åt läsaren att värdera behovet av förändring även om jag tycker att en närmare diskussion av fältens skilda konstruktioner av valfrihetsfrågan skulle ha varit spännande. En annan fråga är om det finns fall där lärandet skulle kunna gå $i$ andra riktningen. Finns det exempelvis problem med ambitionerna att förändra, som ju intuitivt framstår som bättre än ambitionerna att bevara?

Om jag avslutningsvis ska summera mina omdömen så menar jag att Erlandsson har skrivit en mycket bra avhandling som jag har haft stort nöje av att läsa. De resultat hon presenterar är intressanta, viktiga och delvis upprörande. Men kommer någon att bli upprörd? Och vem i så fall? Det återstår att se.

\section{Håkan Jönson}

Fakultetsopponent, Socialhögskolan, Lunds universitet 